\title{
SEVERAL SETS OF ASSUMPTIONS \\ FOR THE MONTE CARLO SIMULATION \\ FOR A MORE PRECISE ANALYSIS OF ENTERPRISE RISK
}

\author{
Jan Kaczmarzyk \\ University of Economics in Katowice, Katowice, Poland \\ e-mail: jan.kaczmarzyk@ue.katowice.pl \\ ORCID: 0000-0002-4139-8858 \\ (C) 2019 Jan Kaczmarzyk \\ This is an open access article distributed under the Creative Commons Attribution-NonCommercial- \\ -NoDerivs license (http://creativecommons.org/licenses/by-nc-nd/3.0/)
}

DOI: 10.15611/eada.2019.4.06

JEL Classification: G32

\begin{abstract}
The traditional methods of risk quantification include a sensitivity analysis, a scenario analysis and a historical simulation. The true nature of risk factors changes is ignored in the traditional 'ceteris paribus' approach to a sensitivity analysis, hence it can be reflected in a scenario analysis and a historical simulation. The most significant disadvantage of a scenario analysis is the limited number of scenarios, whereas a historical simulation depends on historical data availability and adequacy. The Monte Carlo simulation is a clear answer to the limitations of traditional methods. The changes of risk factors reflected in the Monte Carlo simulation are simultaneous, non-linear and interdependent. The most important aspect of this method is the stage of taking up the assumptions. The purpose of the paper is to indicate that considering several reasonable sets of assumptions for the Monte Carlo simulation simultaneously can bring even more comprehensive information about enterprise risk.
\end{abstract}

Keywords: corporate finance, risk analysis, Monte Carlo simulation.

\section{Introduction}

A volatile economic environment is the source of enterprise risk. Risk awareness suggests forecasting the future financial situation of an enterprise. Therefore, every serious professional financial manager should have the ability to project the future financial situation of the enterprise they are responsible for. The basic way of forecasting is simply to look for the most likely to happen scenario of the future financial situation. However, the volatility of the economic environment naturally suggests multiple scenarios that might actually happen in the real world, thus the forecasting process should involve risk assessment. The basic solution is to build a few scenarios. Such a traditional approach to risk assessment is rather limited by 
the number of possible scenarios to be created. The evolution of scenario-based thinking led to the adoption of the Monte Carlo simulation to risk assessment. The basic advantage of the Monte Carlo simulation is the possibility to consider as many scenarios as possible. The simultaneous, interdependent and non-linear changes of risk factors (common in real economic conditions) are easily reflected in the simulation. One of the biggest problems is the assumptions being made for a simulation which depend on the decision of the individual responsible for risk analysis. The assumptions consist of chosen risk factors with specified probability distributions (theoretical distribution types and their parameters), the interdependencies between the risk factors and the chosen risk variables. The purpose of the paper is to indicate that considering several reasonable sets of assumptions for the Monte Carlo simulation simultaneously can bring even more comprehensive information about enterprise risk and enable more effective decision-making.

\section{The quantitative and qualitative assessment of risk exposure}

Every contemporary enterprise is exposed to numerous external and internal risk factors that affect entrepreneurial activity simultaneously, interdependently and non-linearly. Shareholders are typically willing to give their own equity to the enterprise, as long as it guarantees an accepted rate of return. The rate of return should compensate for the level of risk to be taken by becoming involved [Chapman 2006, p. 8].

The quantification should be the basic word, term, criteria and aim when an economic entity considers its risk exposure. Knight's definition of risk states it very clearly: "It will appear that a measurable uncertainty, or 'risk' proper, as we shall use the term, is so far different from an unmeasurable one that it is not in effect an uncertainty at all. We shall accordingly restrict the term 'uncertainty' to cases of the non-quantitative type" [Knight 1921, p. 20]. In the real world there are both entities which tend to quantify and entities which tend to categorise risk while performing risk analysis.

The quantification aims at the probability distribution of the risk variable (e.g. there is a $15 \%$ probability that cash flow will fall below 150000 next year), whereas the categorisation tries to answer that with a category (e.g. there is a low probability that cash flow will fall below 150000 next year). The quantification gives something which is objective for many different entities and, more importantly, comparable for them. The categorisation gives something which in fact can be anything for anyone, therefore the problem of accepting risk seems to be very important and not so obvious among economic entities.

Every entity is quite ready to accept something that is measured (e.g. the cost per piece is 30) than something that is only categorised (e.g. the cost per piece is low). In terms of risk, someone accepting the result of risk quantification (thus 
accepting the probability) should have been more conscious than someone accepting the result of risk categorisation. Despite the above, the categorisation is still a popular tool of qualitative risk management techniques, such as risk registers, risk mapping etc. [Merna, Al-Thani 2008, pp. 72-76; Institute of Management Accountants 2007, pp. 12-15].

Choosing the right approach to risk measurement in the risk management process is essential. The tools and techniques in use should aim at obtaining the probability distributions of risk variables. To be precise, they should aim at the probability distributions of risk variables with the highest level of detail which is possible to achieve in the given circumstances.

\section{The traditional approach to enterprise risk measurement}

A rationally behaving economic entity should always consider that the expected scenario is not the only one likely to happen in the real world. "Uncertainty means that more things can happen than will happen. Whenever you are confronted with a cash-flow forecast, you should try to discover what else can happen" [Brealey et al. 2014, p. 248]. There are two general, traditional and very popular ways to assess what is possible to happen and how it is going to affect an economic entity and its entrepreneurial activity - a sensitivity analysis and a scenario analysis.

There are several forms of sensitivity analysis, such as the analysis of the risk variable reaction to the risk factor change assuming that the range of the considered deviation of the risk factor is given, the analysis of the risk variable reaction to the $1 \%$ risk factor change (flexibility analysis), the analysis of the risk variable level for the particular level of the risk factor, the analysis of the threshold level of the risk factor in terms of which the risk variable level meets the satisfying requirement, or the analysis of the admissible percentage change of risk factors in terms of which the risk variable level meets the satisfying requirement [Rogowski 2016, p. 452]. The typical analysis of the degrees of operational (DOL), financial (DFL) and total leverage (DTL) are also the forms of sensitivity analysis very popular in corporate finance practice (see e.g. [Brealey et al. 2014, pp. 253-254; Sierpińska, Jachna 2007, pp. 414-422; McDaniel 1984, pp. 113-125]).

In terms of sensitivity analysis, it must be stated that this "technique involves taking a single variable (...) and examining the effect of changes in the selected variable on the likely performance of the business" [Chapman 2006, p. 176]. Taking a single variable means assuming 'ceteris paribus' that other variables are not changing at the same time. Such a feature is a limitation, because in the real world risk factors change simultaneously [Golden, Golden 1987, p. 57]. A typical sensitivity analysis "becomes unmanageable if we change several factors at the same time" [Fabozzi, Peterson 2003, p. 464]. Apart from the 'ceteris paribus' assumption, the "problem with sensitivity analysis is that the underlying variables are likely to be interrelated." [Brealey et al. 2014, p. 250]. The final limitation 
of the traditional sensitivity analysis is that it puts aside the probability that the particular deviation of risk factor is likely to occur [Golden, Golden 1987, pp. 56-57]. The changes of risk factors in the real world are obviously simultaneous, interdependent and non-linear. Taking into account the limitations of the traditional sensitivity analysis mentioned above - these three important features are ignored in the basic approach to the sensitivity analysis.

The analysis of scenarios can be the partial solution of reflecting the closest to their real nature changes of risk factors. "A scenario analysis is a top-down, 'what-if' analysis that measures the impact that a certain event (or combination of events) will have on the enterprise" [Lam 2003, p. 110]. "Scenario analysis is unlike sensitivity analysis, in that it will involve changing a number of variables simultaneously in order to portray a possible outcome" [Chapman 2006, p. 177]. "If the variables are interrelated, it may help to consider some alternative plausible scenarios" [Brealey et al. 2014, p. 250]. A common approach to the scenario analysis assumes finding an optimistic, a pessimistic and a most likely view of future events [Chapman 2006, p. 177]. There is also the approach which suggests assigning subjective probability to the scenarios under consideration [Tarczyński, Mojsiewicz 2001, p.148]. This is an arguable concept because the probability is assigned to the risk variable directly, regardless of the probability distributions of the risk factors. The risk variable is usually affected by more than one risk factor, and thus assigning probability to the risk factor rather than to the risk variable is much more convincing. The most significant disadvantage of the scenario analysis is the limited number of scenarios which can be derived and considered by an individual [Pera 2010, p. 124; Rogowski 2016, p. 473].

Both the sensitivity analysis and the scenario analysis require a computer financial model of an enterprise activity or its part to be developed. The model itself generates risk, called model risk. Model risk is a risk derived from errors in the theoretical model being used in the real world [Jajuga 2007, p. 25]. "Unfortunately, model risk is very insidious. Assessing this risk requires an intimate knowledge of the modelling process" [Jorion 2007, p. 26]. "Models can fail for a number of reasons: (1) The input data can be wrong, (2) the parameters of the model can be incorrectly estimated, (3) the model can be incorrect, and (4) the model can be incorrectly implemented" [Jorion 2007, p. 546]. There is no question about the expected nature of the model - it should reflect the real world. The better the model is, the more convincing the risk measurement will be. It should be also mentioned that "models (...) are metaphors that compare the object of their attention to something else that it resembles. Resemblance is always partial, and so models necessarily simplify things and reduce the dimensions of the world" [Derman 2011, p. 6].

The past may also be a reliable source of scenarios. There is a popular risk assessment technique called historical simulation. It is based on the use of empirical probability distributions [Best 2000, p. 48]. There are two general analytical situations possible when using historical simulation: 1. empirical 
distributions are available for both the risk factor or the risk factors and the risk variable or the risk variables, 2. empirical distributions are available for the risk factor or the risk factors only. The first situation does not require developing a computer financial model for processing data and quantifying risk. The second situation requires the computer model to obtain the probability distribution of a risk variable instead; otherwise, at least the historical data of the risk factor or the risk factors are required for the historical simulation to be successful.

The core concept of a historical simulation is to assume that the historical changes of risk factors and risk variables (historical scenarios) can represent their future changes (future scenarios) (see e.g. [Hull 2012, pp. 309-310]). Even though historical data/empirical probability distributions can resemble extreme events better than theoretical ones, there is always the problem of data availability, adequacy as well as the problem of the subjectively chosen and set present values of risk factors or variables.

Historical simulation also enables sensitivity analysis. Having the risk factor and risk variables probability distributions to hand at the same time gives the possibility to conduct the sensitivity analysis using, for example, a linear regression tool. The most significant example of such a sensitivity analysis in terms of financial risk is Sharpe's model [Sharpe 1964, pp. 438-439]. Historical simulation operates on the empirical distributions of risk factors which automatically reflect the eventual interdependent, simultaneous and non-linear changes of risk factors (e.g. if an enterprise is exposed to risk factors which are exchange rates EUR/PLN and USD/PLN, their historical changes are certainly interrelated, they change at the same time and their possible deviations from the most expected change or average change are not of an equal probability). Thus sensitivity analysis through historical simulation should be perceived as an extended solution, especially when compared with traditional 'ceteris paribus' approach discussed earlier.

Unfortunately, having the empirical data for every identified risk factor is practically impossible in most analytical cases, especially in small and medium non-financial enterprises which do not perform economic data collection with the level of precision typical for financial enterprises such as banks or funds. The empirical data for the risk factors that affect non-financial enterprise activity is usually partial, therefore the use of historical simulation is rather limited in this case.

\section{The essence of the Monte Carlo simulation}

Even though the Monte Carlo simulation was adopted (not created) in the world of modern finance [Hertz 1964, pp. 95-106], it clearly addressed the disadvantages of the traditional methods of measuring risk. "Sensitivity analysis allows you to consider the effect of changing one variable at a time. By looking at the project 
under alternative scenarios, you can consider the effect of a limited number of plausible combinations of variables. Monte Carlo simulation is a tool for considering all possible combinations" [Brealey et al. 2014, p. 254]. "The thinking behind simulation is similar to the idea of carrying out multiple manual what-if scenarios" [Chapman 2006, p. 177], (compare [Lam 2003, p. 111; Golden, Golden 1987, p. 54]). A simulation is the core element of the Monte Carlo approach. The outcome of each iteration is a scenario of risk factors generated randomly with regard to the probability distributions of the risk factors. The randomly generated scenarios are processed in the financial model developed for a particular decision problem in order to calculate the corresponding values of the risk variables [Vose 2008, p. 45; Rees 2008, p. 137; Gentry, Pyhrr 1973, p. 70; Hertz 1964, p. 102]. Having been processed in the model, the scenarios of the risk factors are filled with the accompanying scenarios of risk variables (Figure 1).

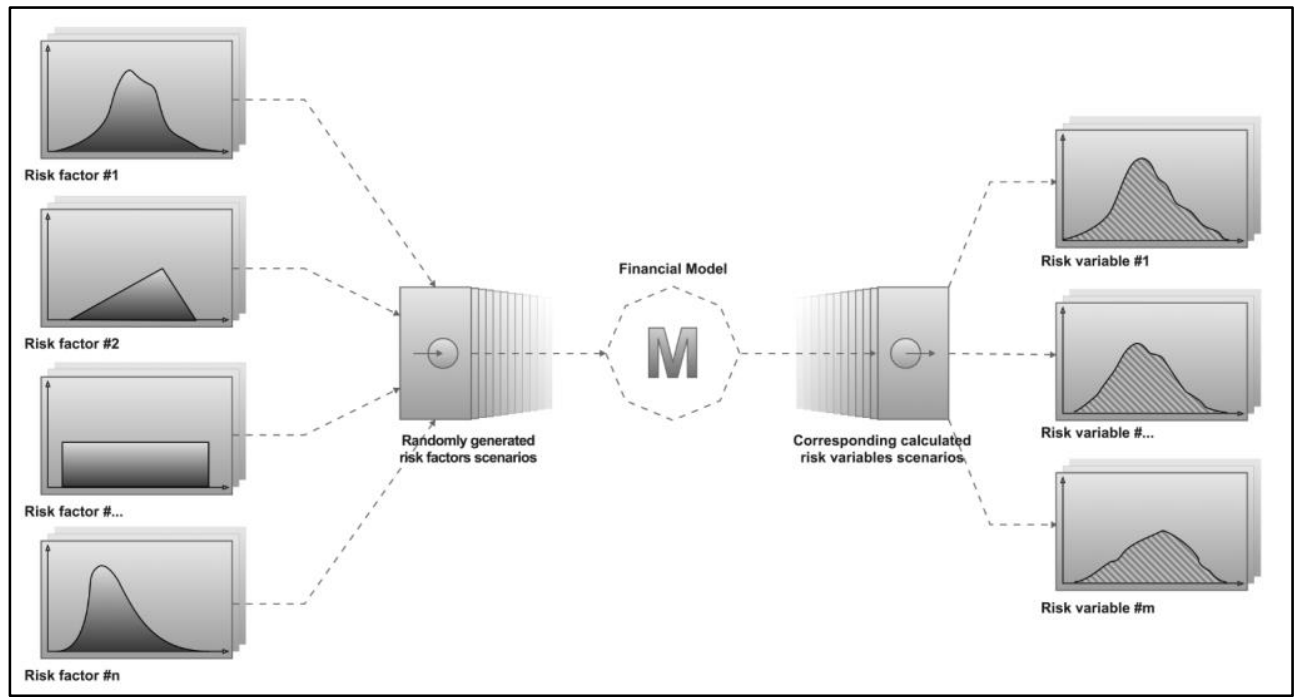

Fig. 1. The mechanism of the Monte Carlo simulation as a scenario technique

Source: own elaboration on the basis of [Kaczmarzyk 2010, p. 231].

The fact that the Monte Carlo technique can be easily used for a scenario analysis in finance is its great strength. In finance it is also a very important tool for analysing complex financial products [Kroese et al. 2014, p. 388]. The Monte Carlo approach as a scenario technique is also very similar to historical simulation. The most significant disadvantage of historical simulation is in fact the access to the empirical data of risk factors. Not having to hand the data associated with one of the risk factors crosses out the risk analysis as explained earlier. The Monte Carlo simulation can be based on probability distributions chosen in an objective way, a quasi-objective way or a subjective way. "The essence of the objective and 
the quasi-objective way is that the risk factor probability distribution is obtained from historical data. The objective way assumes that historical probability distribution suits a particular analytical situation, whereas the quasi-objective way tends to modify the historical probability distribution by changing the expected value or volatility range, while the essence of the subjective way is the use of special probability distribution types for risk factors with an expert opinion as a primary source of information" [Kaczmarzyk 2016b, p. 100 (see also [Hull 2012, pp. 425-426; Vose 2008, p. 263, 393; Kaczmarzyk 2013, p. 25]). Therefore not having the historical data of risk factors to hand does not cross out the risk analysis when using the Monte Carlo approach, unlike when using the historical simulation. Furthermore, when the historical data seems to be inadequate to future economic conditions, the empirically obtained distribution may be modified by changing the expected value, the volatility range (or other parameters specific for the particular type of the distribution) or even the type of the distribution itself.

The Monte Carlo simulation operates on the probability distributions separately chosen for the risk factors. As a result, every risk factor has its own individual volatility range. Furthermore, depending on the type of the distribution attributed to the risk factor, the possible, various deviations of the risk factor can have a different probability of occurrence. In this way the changes of risk factors reflected in the Monte Carlo simulation are not only simultaneous, but also non-linear. Due to advanced techniques the changes of risk factors may also be interdependent [Vose 2008, pp. 353-392]. There are many solutions available in terms of risk factor changes becoming interrelated, but it seems that Cholesky's decomposition [Wilmott 2006, pp. 1275-1276] is possibly the easiest to be implemented in spreadsheets [Kaczmarzyk 2016b, pp. 102-104].

The Monte Carlo approach itself enables the sensitivity analysis, as the risk analysis outcome consists of the probability distributions of the risk factors and risk variables. It should be mentioned that the scenario values (built of the potential values of the risk factors and risk variables) should be transformed into the percentage changes calculated in relation to their starting or expected values. In this way the sensitivity analysis will be as clear as possible. The strongest advantage of the Monte Carlo simulation in terms of sensitivity analysis is the possibility to reflect simultaneous, non-linear and interdependent changes of the risk factors. None of these features of risk factor changes is reflected in the traditional sensitivity analysis (see more on the so-called 'extended sensitivity analysis' in [Kaczmarzyk, Zieliński 2010, pp. 171-187]).

"By the central limit theorem, this method generates estimates whose standard error decreases at the rate of $1 / \sqrt{\mathrm{K}}$, which does not depend on the size of the sample space" (where $\mathrm{K}$ is the number of random samples for the vector of variables) [Jorion 2007, p. 309]. " Monte Carlo simulation is often criticised as being an approximate technique. However, in theory at least, any required level of precision 
can be achieved by simply increasing the number of iterations in a simulation" [Vose 2008, p. 45]. The more scenarios are being generated, the worse the performance of the Monte Carlo simulation is. It actually depends on the IT environment that is used for the simulation. In the case of popular spreadsheets the performance is rather low (when compared to the other environments that are available), but there is a huge difference in speed between modern multi-core systems available even on mobile devices and the devices which are 10 or 20 years older. In other words, there are no real obstacles, even with spreadsheets, to simulate nowadays a hundred thousand scenarios.

Even though the Monte Carlo simulation addresses all the mentioned disadvantages of traditional risk analysis methods, it is not as popular as its quite convincing advantages might have suggested it to be. Some recent research into enterprise risk management conducted in Poland indicated that only $2 \%$ of entrepreneurs made use of the Monte Carlo approach in investment profitability assessment, another $2 \%$ performed enterprise valuation, while $38 \%$ admitted not knowing the Monte Carlo approach and 58\% said they had not used this technique [Kasiewicz 2011, p.183]. In fact the concept of Enterprise Risk Management as an integrated approach (integrated structure) includes clear directions in terms of risk quantification too. The Monte Carlo approach is among the suggested tools and techniques together with the sensitivity analysis and the scenario analysis [The Committee of Sponsoring Organizations of the Treadway Commission 2004, pp. 168-171] (see also [Chapman 2006, pp. 176-180; Lam 2003, p. 111]). The Monte Carlo simulation should probably have been better popularised as a friendly tool for comprehensive risk analysis allowing for considering the 'nearly-allpossible' scenarios rather than as a complicated method.

There are many significant applications of the Monte Carlo simulation in corporate finance. It is used for enterprise valuation (e.g. [Schiefner, Schmidt 2004, pp. 474-490; Manate, Fărcas 2010, pp. 59-69; Tarnóczi et al. 2010, pp. 788-794]) and even suggested for companies that are not publicly traded [Sinevičiene 2007, p. 253]. The Monte Carlo simulation is very effective in corporate investment appraisal (e.g. [Hertz 1964, pp. 95-106, Golden, Golden 1987, pp. 53-64]). An enterprise may adopt this method in prospective financial analysis, too (e.g. [Kaczmarzyk 2016a, pp. 23-37]).

Thinking in terms of scenarios or simply scenario-based thinking seems to be a natural aspect of any rational individual responsible for managing finance under risk exposure. The Monte Carlo approach has been the best solution for risk analysis so far, although it requires a reasonably professional quantitative knowledge. The word 'professional' has to be precisely explained and should not be exaggerated in any way. The method involves quite basic mathematics required to perform the simulation of risk [Vose 2008, p. 45]. The individual should understand both the mechanism of the Monte Carlo approach as an effective all- 
possible-to-happen scenarios generator, as well as the probability distribution of the risk factor or risk variable as a source of risk information. The word 'professional' does not mean that, for example, the individual must exactly understand how to get an inverse function from a cumulative distribution function for every type of theoretical probability distribution. It means that the individual has to know why this function is essential to get a random number with a chosen distribution type - a number being a part of the simulated scenario, a number representing a possible state of risk factor etc.

\section{Using several sets of assumptions for the Monte Carlo simulation}

The most important aspect of the Monte Carlo approach to measuring risk is the stage of making assumptions in terms of risk factors probability distributions and interdependencies between risk factors. The uncertainty about the correctness of the assumptions is an obvious example of the rational thinking of an individual. This uncertainty should be managed in any case.

The definite solution for the Monte Carlo approach could be derived from the idea of traditional scenario analysis. Not being certain about the assumed parameters, an individual may consider preparing several sets of assumptions for the Monte Carlo simulation. The idea is to prepare a positive, a negative and a most likely set of assumptions including probability distributions types, parameters and interdependencies.

In this concept, the negative set of assumptions would assume lower or higher expected values of risk factors depending on their nature of being a booster or an inhibitor in terms of the economic activity of an enterprise. The negative set of assumptions could assume wider volatility ranges for risk factors reflecting the higher probability of extreme change. The negative set of assumptions would also mean changing the correlations between the risk factors. A higher positive correlation between the two boosters or the two inhibitors would mean a higher chance for them to change in the same direction, and thus the higher volatility of the critical synthetic financial category (e.g. correlated unit prices changes in relation to overall sales change - a synthetic financial category). The positive set of assumptions should be perceived in the opposite way - higher boosters, lower inhibitors, narrower volatility ranges and weaker correlations.

Financial categories and ratios as risk variables have their threshold levels or their accepted ranges. These levels or ranges may vary among different individuals responsible for running an enterprise. Setting a minimum level or an accepted range of a financial category or ratio (e.g. enterprise market value, cash flow, earnings or return on equity etc.) is the materialization of entrepreneurial aim. The Monte Carlo approach involved in the risk analysis process gives the probability 
level at which a financial category or ratio can meet individual expectations [Kaczmarzyk 2016a, pp. 23-37; Helfert 2000, p. 282-283]. The difference between the Monte Carlo approach and traditionally perceived scenarios is in risk information quality. The main idea of both methods is the same. The final quality depends on the level of detail given by the probability distribution brought by the method which is incomparably higher with the Monte Carlo approach (Figure 2). The result of a typical financial forecast (1) is only a forecasted level of a financial category or ratio confronted with a threshold level or an accepted range. Involving the traditional scenario analysis, (2) brings a low-quality probability distribution of a risk variable. The main problem is that assigning probability directly to the risk variable by stating the probability level subjectively (e.g. Scenario S1 $-50 \%$, Scenario $\mathrm{S} 2-15 \%$ etc.) does not mean risk quantification. In fact, it does not differ significantly from risk categorisation (which would be e.g. Scenario S1 - highly

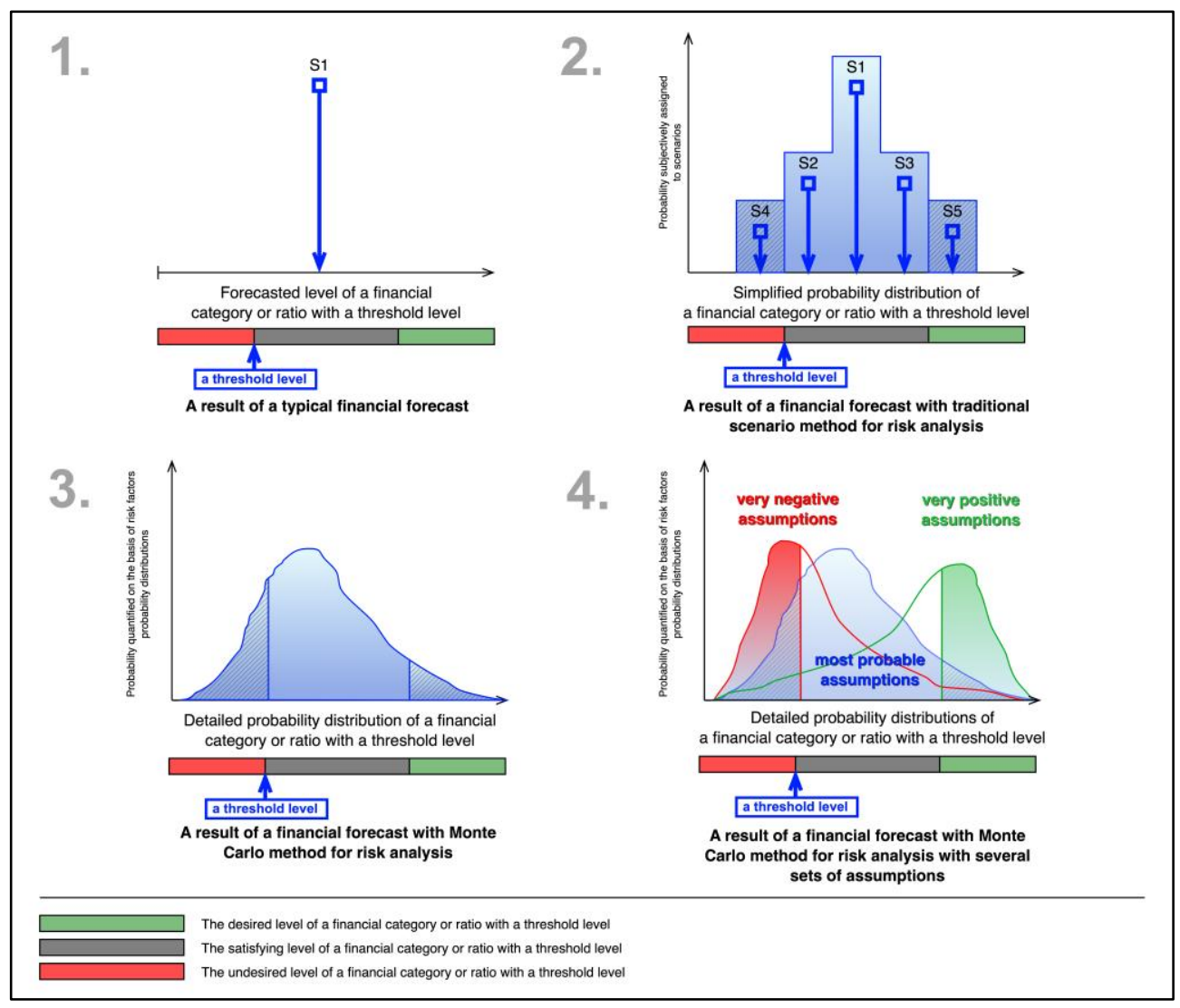

Fig. 2. The approaches to risk analysis comparison

Source: own elaboration on the basis of [Kaczmarzyk 2016a, pp. 23-37]. 
expected, Scenario S2 - moderately expected etc.). Using the Monte Carlo method brings the most accurate probability distribution of the risk variable which is quantified on the basis of the risk factor probability distributions (3). In terms of financial planning, one moves from the one-point estimate (1) to the multipoint estimate (2) and finally to the "nearly-all-points" estimate (3) (see e.g. [McCarthy 1994, pp. 111-115]).

The concept of using several sets of assumptions for the Monte Carlo simulation (4) moves towards having more than one probability distribution for every risk variable - the negative, positive and most likely probability distribution per considered sets of assumptions. The comparison of the probability levels quantified for each set of assumptions is then the key decision tool (Figure 2). The risk variable threshold level can be described then with three probabilities $\left(\alpha_{V N}, \alpha_{M P}\right.$, $\left.\alpha_{V P}\right)$ or respectively three confidence levels $\left(1-\alpha_{V N}, 1-\alpha_{M P}, 1-\alpha_{V P}\right)$ quantified using cumulative distribution functions [Jajuga 2007, p. 47; Vose 2008, p. 115] $(\mathrm{CDF})$ :

$$
\begin{aligned}
& C D F_{V N}(T L)=P(X \leq T L)=\alpha_{V N}, 1-\alpha_{V N} \\
& C D F_{M P}(T L)=P(X \leq T L)=\alpha_{M P}, 1-\alpha_{M P} \\
& C D F_{V P}(T L)=P(X \leq T L)=\alpha_{V P}, 1-\alpha_{V P},
\end{aligned}
$$

where: $C D F_{V N}, C D F_{M P}, C D F_{V P}$ - cumulative distribution functions for the risk variable threshold level (derived respectively for the very negative, most probable and very positive set of assumptions);

$T L$ - risk variable threshold level;

$\alpha_{V N}, \alpha_{M P}, \alpha_{V P}-$ the probability that risk variable $X$ is equal or below the threshold level;

$1-\alpha_{V N}, 1-\alpha_{M P}, 1-\alpha_{V P}-$ the confidence level that risk variable $X$ is going to exceed the threshold level.

Decisions are always related to an individual and his or her risk aversion. Example risk analysis results ${ }^{1}$ should clarify the concept of using several sets of assumptions. Let us take a risk variable with a threshold level that should be exceeded. Risk would be clearly acceptable if confidence levels for the all considered sets of assumptions for a threshold value were relatively high (Figure 3), while risk should not be undertaken if confidence levels were relatively low (Figure 4). The closer to each other the confidence levels will be, the more unequivocal the final decision is going to be for an individual (Figure 5). When an accepted range becomes a decisive criterion, the most important question is whether the probability of falling into an accepted range - derived for negative assumptions - is acceptable (Figure 6).

1 The example results were derived using Palisade @RISK 7.6.1 using Pert probability distributions. 

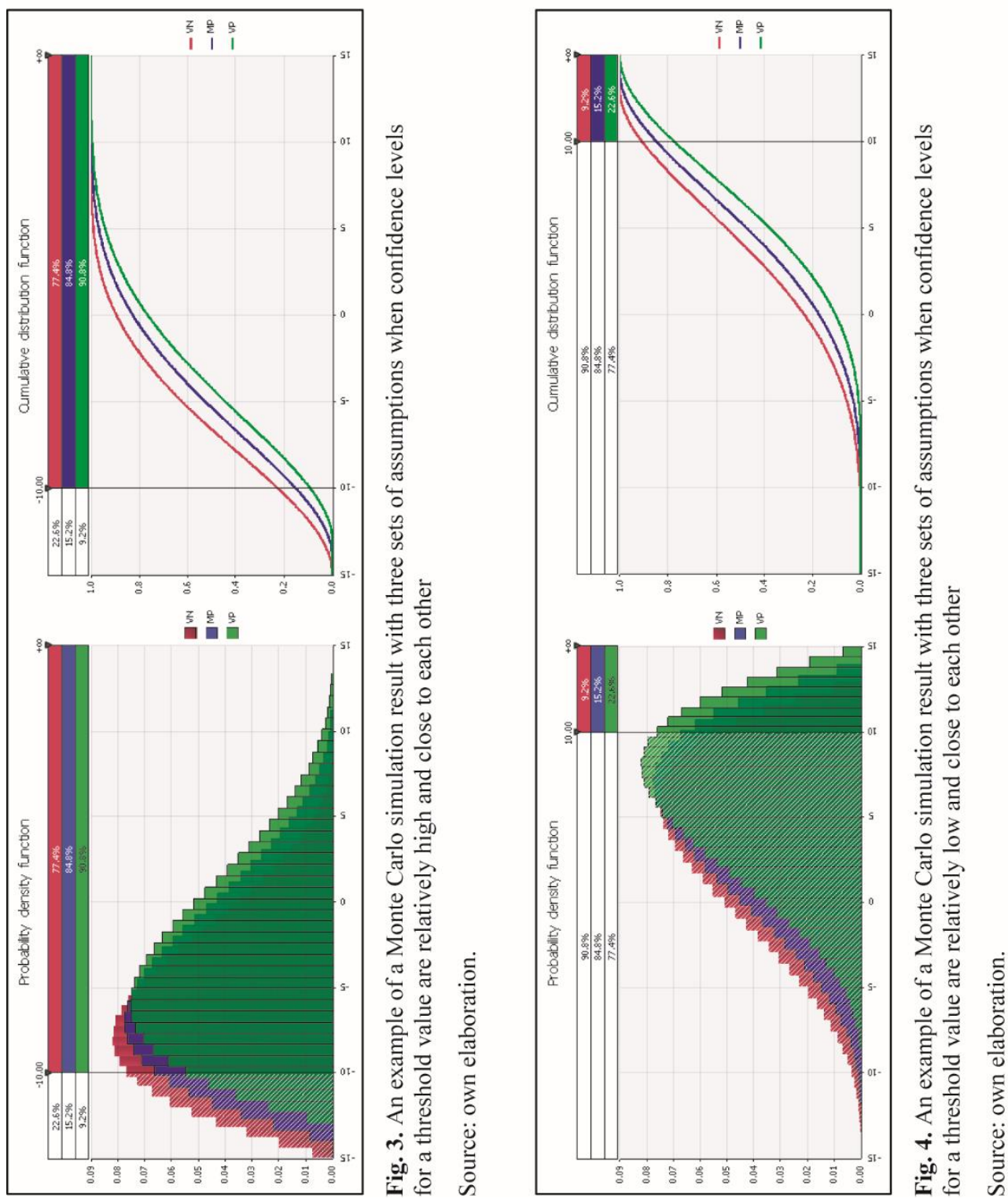

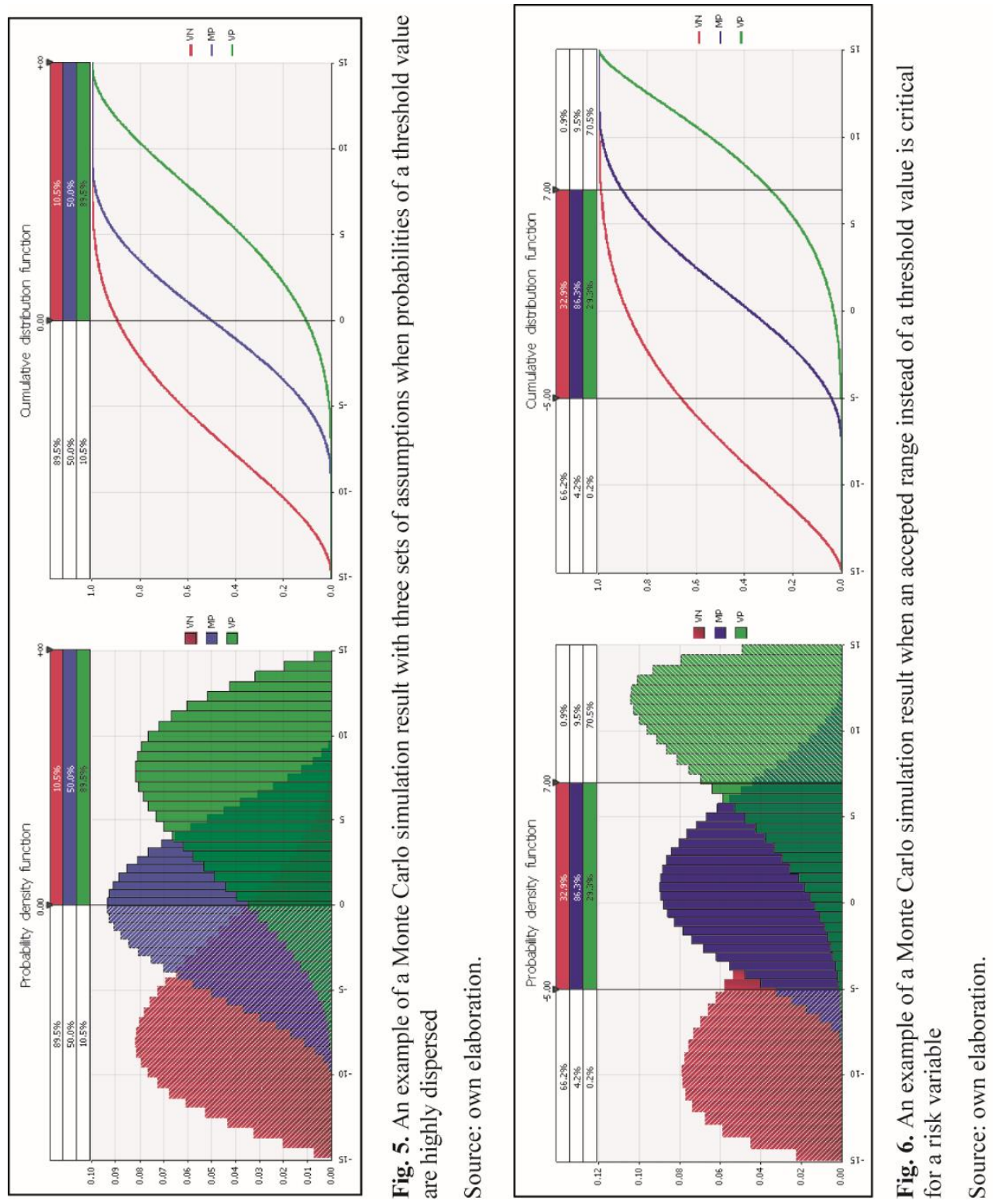
Every set of assumptions should be precisely described and legitimised, and thus every change in the risk factors expected value, volatility range or interdependency should be explained while making the sets of assumptions. Obviously, there could be more than three sets under consideration, but this would certainly complicate undertaking decisions by individuals. Even though the concept of using several sets of assumptions for the Monte Carlo simulation seems to be a comprehensive approach to risk analysis, it is still based on a computer financial model of an enterprise which generates model risk itself. The quality of the model understood as the ability to resemble economic reality seems to be a big corresponding issue. Both traditional risk analysis methods and the Monte Carlo simulation are based on the use of a computer financial model, so this type of model risk affects their outcomes in the same way. The use of the several sets of assumptions tries to deal with the risk arising from the assumptions of the Monte Carlo simulation that could have been mistakenly made.

\section{Conclusions}

Choosing the right approach to risk measurement in the risk management process is essential. Unquestionably, the risk factors change simultaneously, interdependently and non-linearly in the real economic environment. The traditional methods of risk quantification include sensitivity analysis, scenario analysis and historical simulation. The true nature of risk factor changes is ignored in the traditional 'ceteris paribus' approach to the sensitivity analysis, hence it can be reflected in the scenario analysis and the historical simulation. The most significant disadvantage of the scenario analysis is the limited number of scenarios, whereas the historical simulation depends on historical data availability and adequacy. The historical simulation gives the possibility to assess risk using the probability distributions of the risk factors and risk variables, and thus it specifies the level of probability at which the risk variables can meet their threshold levels or accepted ranges. In fact there is an approach which suggests attributing probability levels directly to the scenarios derived in traditional scenario analysis, but the output distribution has a much worse quality than what is offered by the historical simulation.

The Monte Carlo simulation offers the possibility to consider as many scenarios as possible even if historical data are not available. Moreover, it reflects the true nature of risk factors changes (as historical simulation). The probability distributions of the risk variables attained using the Monte Carlo simulation can have the desired level of detail. Together with the probability distributions of risk factors, they enable an extended sensitivity analysis. The final problems of the Monte Carlo approach are model risk as well as the correctness of the assumptions. The first problem depends on the model accuracy (the ability to resemble the real world). The second problem can be resolved by making and comparing several sets of assumptions for the Monte Carlo simulation. This concept for the Monte Carlo simulation moves towards having more than one 
probability distribution for risk variable at the same time - the negative, positive and the most expected probability distribution per considered sets of assumptions. The risk variable threshold level or accepted range is to be described then with three probabilities. Such an approach tries to avoid an inaccurate decision that could have been taken due to inadequate assumptions.

\section{Bibliography}

Best P., 2000, Wartość narażona na ryzyko, Oficyna Ekonomiczna, Cracow.

Brealey R., Myers S., Allen F., 2014, Principles of Corporate Finance, McGraw-Hill, New York.

Chapman R., 2006, Simple Tools and Techniques for Enterprise Risk Management, John Wiley \& Sons, West Sussex.

Derman E., 2011, Models Behaving Badly, John Wiley \& Sons, West Sussex.

Fabozzi F., Peterson P., 2003, Financial Management and Analysis, John Wiley \& Sons, New Jersey. Gentry J., Pyhrr S., 1973, Simulating an EPS Growth Model, Financial Management, 2(2), pp. 68-76.

Golden C., Golden M., 1987, Beyond "what if": A risk-oriented capital budgeting model, Journal of Information Systems, 1(2), pp. 53-64.

Helfert E., 2000, Techniques of Financial Analysis. A Guide to Value Creation, McGraw-Hill, Singapore.

Hertz D., 1964, Risk analysis in capital investment, Harvard Business Review, 42(1), pp. 95-106.

Hull J., 2012, Risk Management and Financial Institutions, John Wiley \& Sons, New Jersey.

Institute of Management Accountants [IMA], 2007, Enterprise Risk Management: Tools and Techniques for Effective Implementation, https://erm.ncsu.edu/az/erm/i/chan/m-articles/ documents/IMAToolsTechniquesMay07.pdf.

Jajuga K. (ed.), 2007, Zarzadzanie ryzykiem, PWN, Warsaw.

Jorion P., 2007, Value at Risk. The New Benchmark for Managing Financial Risk. Third Edition, McGraw-Hill, Singapore.

Kaczmarzyk J., 2010, Wybrane aspekty wykorzystania metod symulacyjnych $w$ ocenie ryzyka działalności gospodarczej przedsiębiorstwa, Zeszyty Naukowe Uniwersytetu Ekonomicznego w Poznaniu 142, pp. 227-240.

Kaczmarzyk J., 2013, A subjective approach in risk modelling using simulation techniques, Studia Ekonomiczne Uniwersytetu Ekonomicznego w Katowicach, 127, pp. 23-34.

Kaczmarzyk J., 2016a, Prospective financial analysis with regard to enterprise risk exposure - the advantages of the Monte Carlo method, Financial Sciences, 27 (2), pp. 23-37.

Kaczmarzyk J., 2016b, Reflecting interdependencies between risk factors in corporate risk modeling using Monte Carlo simulation, Econometrics, 52(2), pp. 98-107.

Kaczmarzyk J., Zieliński T., 2010, Metody symulacyjne w poszerzonej analizie wrażliwości, Studia Ekonomiczne Uniwersytetu Ekonomicznego w Katowicach, 71, pp. 171-187.

Kasiewicz S. (ed.), 2011, Zarządzanie zintegrowanym ryzykiem przedsiębiorstwa $w$ Polsce, Wolters Kluwer Polska, Warsaw.

Knight F., 1921, Risk, Uncertainty and Profit, https://mises.org/sites/default/files/ Risk,\%20Uncertainty,\%20and\%20Profit_4.pdf.

Kroese D., Brereton T., Taimre T., Botev Z., 2014, Why the Monte Carlo method is so important today, WIREs Computational Statistics, 6(6), pp. 386-392.

Lam J., 2003, Enterprise Risk Management. From Incentives to Controls, John Wiley \& Sons, New Jersey. 
Manate D., Färcas P., 2010, Model for use of Monte Carlo simulations in business valuation, The Valuation Journal 5(1), pp. 59-69.

McCarthy E., 1994, Using spreadsheet simulations in financial planning, Journal of Financial Planning, 7(3), pp. 111-115.

McDaniel W., 1984, Operating leverage and operating risk, Journal of Business Finance \& Accounting, 11(1), pp. 113-125.

Merna T., Al-Thani F., 2008, Corporate Risk Management, John Wiley \& Sons, West Sussex.

Pera K., 2010, Zintegrowana ocena efektywności finansowej surowcowego projektu inwestycyjnego, Akademia Ekonomiczna, Katowice.

Rees M., 2008, Financial Modelling in Practice, John Wiley \& Sons, West Sussex.

Rogowski W., 2016, Rachunek efektywności inwestycji. Wyzwania teorii i potrzeby praktyki, Wydawnictwo Nieoczywiste, Warsaw.

Schiefner L., Schmidt R., 2004, Shareholder Value at Risk as an Instrument of Company Valuation, [in:] G. Fandel U. Backes-Gellner M. Schlüter and J. Staufenbiel (eds.), Modern Concepts of the Theory of the Firm, Springer, Berlin Heidelberg, pp. 474-490.

Sharpe W., 1964, Capital asset prices: A theory of market equilibrium under conditions of risk, The Journal of Finance, 19(3), pp. 425-442.

Sierpińska M., Jachna T., 2007, Metody podejmowania decyzji finansowych, PWN, Warsaw.

Sinevičienè L., 2007, Vertès nustatymo metodu taikymo aspektai ịmonèse, kuriu akcijomis viešai neprekiaujama, Economics and Management, 12, pp. 247-253.

Tarczyński W., Mojsiewicz M., 2001, Zarządzanie ryzykiem, PWE, Warsaw.

Tarnóczi T., Fenyves V., Tóth R., 2010, Corporate valuation using two-dimensional Monte Carlo simulation, Annals of the University of Oradea, Economic Science Series, 19(2), pp. 788-794.

The Committee of Sponsoring Organizations of the Treadway Commission [COSO], 2004, Zarzadzanie ryzykiem korporacyjnym - zintegrowana struktura ramowa. Techniki zastosowania (Enterprise risk management - integrated framework. Application techniques), WEMA WydawnictwoPoligrafia Sp. z o.o., Warsaw.

Vose D., 2008, Risk Analysis. A Quantitative Guide, John Wiley \& Sons, West Sussex.

Wilmott P., 2006, Paul Wilmott On Quantitative Finance, John Wiley \& Sons, West Sussex.

\section{ZWIĘKSZENIE PRECYZJI ANALIZY RYZYKA W PRZEDSIĘBIORSTWIE POPRZEZ SYMULACJE MONTE CARLO Z ZESTAWAMI ZALOŻEŃ}

Streszczenie: Tradycyjne rozwiązania w zakresie pomiaru ryzyka obejmują analizę wrażliwości, analizę scenariuszy oraz symulację historyczną. Rzeczywisty charakter zmian czynników ryzyka jest pomijany $\mathrm{w}$ tradycyjnej analizie wrażliwości ceteris paribus. Może on być odzwierciedlony w analizie scenariuszy i symulacji historycznej. Najistotniejszą wadą analizy scenariuszy jest ograniczona liczba rozważanych scenariuszy, w przypadku zaś symulacji historycznej - jej poleganie na dostępności danych historycznych oraz kwestia ich adekwatności do sytuacji analitycznej. Monte Carlo odpowiada na ograniczenia metod tradycyjnych. Pozwala ona na odzwierciedlenie jednoczesnych, współzależnych i nieliniowych zmian czynników ryzyka. Najważniejszym aspektem symulacji Monte Carlo jest formułowanie założeń. Celem artykułu jest wskazanie, że rozważenie kilku racjonalnych zestawów założeń symulacji Monte Carlo jednocześnie pozwala pozyskanie wyczerpującej informacji o ryzyku działalności gospodarczej przedsiębiorstwa.

Słowa klucze: finanse przedsiębiorstwa, analiza ryzyka, symulacja Monte Carlo. 